\title{
The Effect Of Return On Assets, Debt To Equity Ratio And Quick Ratio On Dividend Policy
}

\author{
$1^{\text {st }}$ Sri Purwaningsih ${ }^{1}, 2^{\text {nd }}$ Angela Dirman ${ }^{2}, 3^{\text {nd }}$ Nur Miftahul Falah $^{3}$ \\ \{sri.purwaningsih2003@gmail.com ${ }^{1}$, angeladirman@yahoo.com ${ }^{2}$, nurmiftahulfalah@gmail.com ${ }^{3}$ \}
}

Universitas Mercu Buana, Jakarta ${ }^{123}$

\begin{abstract}
This study aims to determine whether the effect of Return On Assets (ROA) on Dividend Policy, Debt to Equity Ratio (DER) on Dividend Policy, and Quick Ratio (QR) on Dividend Policy in manufacturing companies in the consumer goods industry sector listed on the Indonesia Stock Exchange (IDX) for the period 2015-2017. Data obtained by 35 companies with a period of 2015-2017 and the research connected with 4 variables, namely 3 independent variables: Return On Assets (ROA), Debt to Equity Ratio (DER), and Quick Ratio (QR) and 1 dependent variable: Dividend Policy. The analytical method used is the normality test, multicollinearity test, heteroscedasticity test, autocorrelation test, determination test, $\mathrm{t}$ test, and $\mathrm{F}$ test.

The results of this study indicate that: (1)Variable Return on Assets (ROA) does not occur heteroscedasticity and is eliminated, so hypothesis testing is not done, (2) Variables Debt to Equity Ratio (DER) has no affect on Dividend Policy, (3) Variable Quick Ratio (QR) affects on Dividend policy and (4) for the F test results, Debt to Equity Ratio and Quick Ratio simultaneously effect on Dividend Policy.
\end{abstract}

Keywords: Dividend Policy, Return On Assets, Debt to Equity Ratio, quick Ratio

\section{Introduction}

This Word document can be used as a template for papers to be published in Proceedings. Follow the text for further instructions on text formating, tables, figures, citations and references.

M. Hanafi and Abdul Halim $(2016 ; 6)(1)$ mention investors or prospective investors will be interested in the level of profit (return) expected for the future relative to the risk of the company. The most interesting of course is a company that has a high level of profit, but has a low level of risk. If the company's profit level rises, but the company's risk also rises, then the company will not attract anymore. The company will still be attractive if additional benefits can compensate for the additional risks that arise. In general, investors are generally risk averse, so the level of profit and risk factors must be considered together to determine whether a company is attractive or not.

For those who own shares, they will get some benefits as a form of obligation that must be received, namely to get dividends to be given at the end of each year, obtain capital gains, namely profits when the shares owned are resold at more expensive prices, have voting rights for shareholders of the common stock type, such as at the GMS and EGMS, and in taking credit to the bank, the number of shares owned can be used as one of the supporting guarantees or additional guarantees with the aim of making more confident the credit appraiser in seeing the ability of prospective debtors (Irham Fahmi, 2014; 328)(2). 
Kieso $(2018 ; 20)(3)$ states that some of the main reasons companies do not pay dividends in amounts equivalent to the availability of balances legally, one of which is to finance the development or expansion of the company. Another reason is to make a bearing or buffer against possible losses or errors in the calculation of profits. The distribution of dividends can be paid in the form of cash dividends, property dividends, liquidation dividends, and stock dividends. Previous research by Iwan Firdaus (2017), Susan Sumampow and Sri Murni (2016), Aliya Bushra 'and Nawazish Mirza (2015), and Viorela Ligia Vaidean and Corina Zamfira Moza (2015) which concluded that return on assets has a positive effect on results and dividend policy. But there were differences in the results of the research conducted by Zulfa Eka Widya Novianti (2017), Prisilia Karauan et al (2017), and Pornumpai Komrattanapanya (2013) which showed that return on assets did not significantly influence dividend policy $(4)(5)(6)(7)(8)(9)(10)$.

Subsequent research conducted by Herlina Raiza Windyasari (2017) regarding the effect of debt to equity ratio on dividend policy shows the results that the debt to equity ratio has a positive effect on dividend policy. Different conclusions are generated in the study of Ery Teguh Prasetyo (2017) and Ni Ketut Ari Astiti et al (2017), namely the debt to equity ratio does not affect the dividend payout ratio. Other research conducted by Dr. Turkey SF Alzomaia and Mr. Ahmed Al-Khadiri (2013) shows that the debt to equity ratio has a negative effect on dividend policy $(11)(12)(13)(14)(15)$.

\section{Literature Review}

\subsection{Agency Theory}

Agency conflict in the context of agency theory popularized by Jensen and Meckling (1976) in Gumanti $(2013 ; 67)(16)$ is less pronounced in the situation of dividend payments in Indonesia. Agency conflicts in public companies in Indonesia are more common among controlling shareholders (majority shareholders or controlling shareholders) with minority shareholders. With the size of the controlling shareholding portion making conflicts between controlling shareholders and company managers less obvious, the consequences of conflict in the context of agency theory are rare.

Dividend payments can be an embodiment in reducing the level of agency problems between company managers and owners. In addition, the dividend distribution decision at the time of the GMS can be used as a medium to reduce conflict between minority shareholders and majority shareholders (Gumanti, 2013; 67)(16).

\subsection{Signaling Theory}

According to the signal hypothesis (Gumanti, 2013; 64)(16), investors can predict information about the company's future profits through signals that arise from dividend announcements, both their stability and changes. However, managers tend to get more and better information than investors or shareholders, so management will be able to use changes in dividends as a means to communicate that information to the financial market regarding the company's profits and growth in the future.

Dividends contain information about the company's current and future cash flows, and managers have the urge to convey the company's internal information to the market by making 
dividend payments to reduce information gaps. The announcement of a dividend increase will be considered good news for investors, and then it will also be responded to well. Vice versa, if the announcement of the dividend reduction, the response that the investor will give is not good (Gumanti, 2013; 65-66)(16).

\subsection{Return On Assets}

According to Werner R. Murhadi (2015; 64): "Return On Assets reflects how much return is generated on every rupiah invested in assets". The return on assets is a ratio that shows how much the asset contributes to creating net income. In other words, this ratio is used to measure how much net income will be generated from each rupiah of funds embedded in total assets. The higher the return on assets means the higher the amount of net income generated from each rupiah funds embedded in total assets, and before that (17).

Whereas according to Mamduh M. Hanafi and Abdul Halim (2016; 81), the formula for calculating ROA is as follows (1):

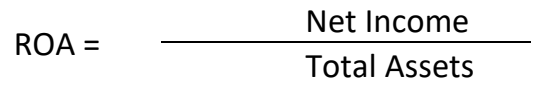

\subsection{Debt to Equity Ratio}

Debt to equity ratio is a ratio used to measure the proportion of debt to capital. The higher the debt to equity ratio means that the smaller the amount of owner's capital can be used as collateral for debt (18).

The formula for finding a debt to equity ratio can be used as a comparison between total debt and total equity as follows (19):

$$
\text { DER }=\frac{\text { Total Debt }}{\text { Total Equity }}
$$

\subsection{Quick Ratio}

Quick ratio is calculated by comparing cash and quick assets on one side with short-term debt on the other. Quick assets consist of accounts receivable and securities that can be realized into money in a relatively short time. Inventories are not taken into account because they are considered to require relatively long time to be realized into money, and there is no certainty whether the inventory can be sold or not (20).

Quick ratio reflects the company's ability to meet current liabilities more tightly. This is due to the lack of liquid assets, such as inventory and prepaid expenses, which are taken out of the calculation. Inventory is issued because it takes time to sell it and turn it into a form of cash. While prepaid expenses are incurred because this account is not a potential source for cash but rather refers to future obligations that have not been fulfilled (17).

The formula for calculating the Quick Ratio according to (21):

$$
\mathrm{QR}=\quad \frac{\text { Total current asset }- \text { inventory }}{\text { Total current liability }}
$$




\section{Research Model, Hypothesis And Research Methodology}

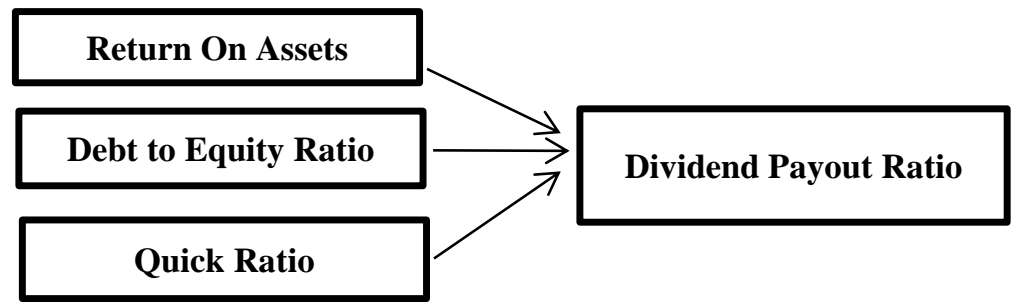

Fig.1. Thinking Framework

Based on the formulation of the problem and the proposed literature review, the hypotheses in this study are as follows:

H1: Return On Asset has a positive effect on Dividend Policy.

H2: Debt to Equity Ratio has a negative effect on Dividend Policy.

H3: Quick Ratio has a positive effect on Dividend Policy.

\section{Result And Discussion}

The population in this study are all manufacturing companies in the consumer goods industry sector that are listed on the Indonesia Stock Exchange (IDX) and publish audited financial statements on the Indonesia Stock Exchange (IDX) website consistently during the study period of 2015-2017. The initial population was obtained by 43 companies. However, after the selection was done by using a purposive sampling method based on predetermined criteria, a total of 105 samples were obtained from 35 companies during the 3 years of the study period.

\subsection{Descriptive statistics}

Descriptive statistical analysis describes a summary of research data such as the amount of data in the same $(\mathrm{N})$, minimum, maximum, average sample (mean), and standard deviation for the variable Return on Assets (ROA), Debt to Equity Ratio (DER), Quick Ratio (QR), and Dividend Payout Ratio (DPR). The results of the descriptive statistical test in this study can be seen in the following table:

Table 1. Source: Output calculation of SPSS version 25 


\begin{tabular}{|c|c|c|c|c|c|}
\hline & $\mathrm{N}$ & $\begin{array}{c}\text { Minimu } \\
\mathrm{m}\end{array}$ & Maximum & Mean & $\begin{array}{c}\text { Std. } \\
\text { Deviation }\end{array}$ \\
\hline ROA & 105 & -15.48 & 52.67 & 8.9429 & 11.39842 \\
\hline DER & 105 & -502.00 & 265.50 & 72.8426 & 78.48714 \\
\hline QR & 105 & 20.28 & 783.68 & 177.9738 & 147.93006 \\
\hline DPR & 105 & .00 & 145.92 & 31.4349 & 34.18121 \\
\hline $\begin{array}{c}\text { Valid N } \\
\text { (listwise) }\end{array}$ & 105 & & & & \\
\hline
\end{tabular}

Based on the table above, the number of samples is 105 . The minimum, maximum, average or mean values and standard deviations can be seen in the table

\subsection{Test the Assumptions and Quality of Research Instruments Normality test}

The normality test aims to test whether in the regression model, the disturbing or residual variables have a normal distribution. Normality testing in this study uses the data normality test graphically using P-Plot with the following results:

Based on the results of the normality test using the Kolmogrov_Smirnov non parametric statistical test, with the following results:

Table 2. One-Sample Kolmogorov-Smirnov Test

\begin{tabular}{|l|l|r|}
\hline \multicolumn{2}{|l|}{} & $\begin{array}{r}\text { Unstandardiz } \\
\text { ed Residual }\end{array}$ \\
\hline $\mathrm{N}$ & 105 \\
\hline \multirow{2}{*}{ Normal Parameters } & Mean & .0000000 \\
\cline { 2 - 3 } & $\begin{array}{l}\text { Std. } \\
\text { Deviation }\end{array}$ & 20.90985188 \\
\hline $\begin{array}{l}\text { Most Extreme } \\
\text { Differences }\end{array}$ & Absolute & .058 \\
\cline { 2 - 3 } & Positive & .058 \\
\cline { 2 - 3 } & Negative & -.045 \\
\hline \multicolumn{2}{|l|}{ Test Statistic } & .058 \\
\hline Asymp. Sig. (2-tailed) & $.200^{\mathrm{c}, \mathrm{d}}$ \\
\hline
\end{tabular}
a. Test distribution is Normal.
b. Calculated from data.
c. Lilliefors Significance Correction.
d. This is a lower bound of the true significance.

\subsection{Multicollinearity Test}

The multicollinearity test aims to test whether the regression model found a correlation between independent variables. A good regression model should not have a correlation between the independent variables. If the independent variables correlate with each other, then these variables are not orthogonal. Orthogonal variables are independent variables whose correlation value between each independent variable is zero (Ghozali, 2016; 103)(22). The following table results of multicollinearity tests conducted in this study: 
Table 3. Output perhitungan SPSS versi 25

\section{Coefficients $^{\mathrm{a}}$}

\begin{tabular}{|l|l|l|l|}
\hline \multirow{2}{*}{ Model } & \multicolumn{2}{|l|}{ Collinearity Statistics } \\
\cline { 3 - 4 } 1 & Tolerance & VIF \\
\hline \multirow{5}{*}{1} & (Constant) & & \\
\cline { 2 - 4 } & ROA & 860 & 1.163 \\
\cline { 2 - 4 } & DER & 804 & 1.245 \\
\cline { 2 - 4 } & QR & .790 & 1.266 \\
\hline
\end{tabular}

a. Dependent Variable: DPR

Based on the table above, it is known that all independent variables have a Tolerance value > 0.10 and Variance Inflation Factor value $(\mathrm{VIF})<10$, so it can be concluded that the independent variable used in the regression equation model has no multicolonity or there is no very strong relationship between independent variables .

\subsection{Autocorrelation Test}

The autocorrelation test aims to test whether in the linear regression model there is a correlation between the confounding errors in period $t$ and the interfering errors in the $t-1$ period (before). If there is a correlation, then there is an autocorrelation problem. The autocorrelation test in this study used the Durbin-Watson test (DW Test) where the presence or absence of autocorrelation was determined as follows:

H0: $\mathrm{du}<\mathrm{d}<4-\mathrm{du}$ (no autocorrelation)

Table 4. Model Summary ${ }^{\mathrm{b}}$

\begin{tabular}{|l|l|r|r|r|r|}
\hline Model & $\mathrm{R}$ & $\begin{array}{c}\mathrm{R} \\
\text { Square }\end{array}$ & $\begin{array}{r}\text { Adjusted } \\
\text { R Square }\end{array}$ & $\begin{array}{c}\text { Std. Error of } \\
\text { the Estimate }\end{array}$ & $\begin{array}{c}\text { Durbin- } \\
\text { Watson }\end{array}$ \\
\hline 1 & $.791^{\mathrm{a}}$ & .626 & .615 & 21.21812 & 1.845 \\
\hline
\end{tabular}

a. Predictors: (Constant), QR, ROA, DER

b. Dependent Variable: DPR

Sumber : Output perhitungan SPSS versi 25

Based on the data presented in the table above, it is known that the Durbin-Watson value is 1,845 , the value will be compared with the value in the Durbin-Watson table that uses a $5 \%$ significance value for the sample number 105 (n) and the number of independent variables $3(\mathrm{k}$ $=3$ ) The following are the values in the Durbin-Watson table:

Table 5. Durbin-Watson (DW), $a=5 \%$

\begin{tabular}{|c|c|c|c|c|c|}
\hline $\mathrm{n}$ & $\mathrm{k}$ & $\mathrm{Dl}$ & $4-\mathrm{dl}$ & $\mathrm{du}$ & $4-\mathrm{du}$ \\
\hline 105 & 3 & 1.6237 & 2.3763 & 1.7411 & 2.2589 \\
\hline
\end{tabular}

From the two tables above, it can be seen that the Durbin Watson value in this study is between the du value and the 4-du value or the Durbin Watson value 1.845 is greater than the 
upper limit value du 1.7411 and smaller than the 4-du value 2.2589, so it can be concluded that there is no autocorrelation.

\subsection{Heteroscedasticity Test}

Heteroscedasticity test aims to test whether in the regression model variance and residual inequalities occur one observation to another observation. To detect the presence or absence of heteroscedasticity, researchers conducted a test using the Glejser test, with the following results:

Table 6. Coefficients ${ }^{\mathrm{a}}$

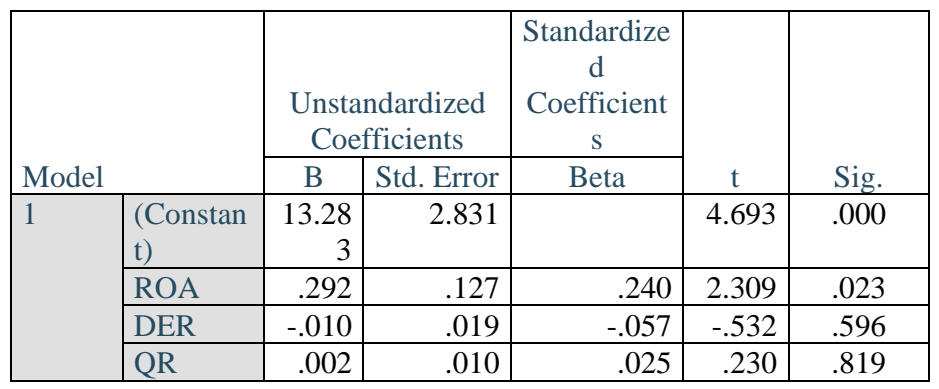

a. Dependent Variable: Abs_Res

Based on the data presented in the table above, it is known that the Sig values for each variable ROA, DER, and QR are 0.023, 0.596, and 0.819. In the glejser test, a data is said to have no heteroscedasticity if the Sig value is $>0.05$, so that from the regression test it is concluded that in the ROA variable heteroscedasticity occurs. To overcome this, the researcher eliminated the ROA variable in the next test.

Table 7. Source: Output calculation of SPSS version 25

Coefficients $^{\mathrm{a}}$

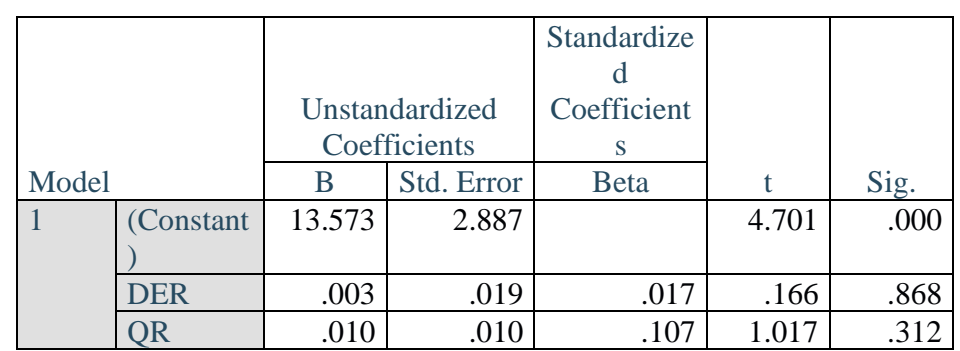

a. Dependent Variable: Abs_Res

After eliminating the ROA variable, the server test is performed again on the DER and QR variables presented in the table. Based on the table above, it is known that the Sig values for each DER and QR variable are 0.868 and 0.312 . So that it can be concluded that the two variables did not occur heteroscedasticity.

\subsection{Hypothesis testing}

Determination Coefficient Test 
The coefficient of determination (R2) is used to measure how far the ability of the independent variables namely Debt to Equity Ratio and Quick Ratio in explaining the variation of the dependent variable is the Dividend Payout Ratio.

Table 8. Model Summary ${ }^{\mathrm{b}}$

\begin{tabular}{|c|c|c|c|c|}
\hline \multirow[b]{2}{*}{ Model } & \multirow[b]{2}{*}{$\mathrm{R}$} & \multirow[b]{2}{*}{ R Square } & \multirow[b]{2}{*}{$\begin{array}{l}\text { Adjusted R } \\
\text { Square }\end{array}$} & \multirow{2}{*}{$\begin{array}{l}\text { Std. Error } \\
\text { of the } \\
\text { Estimate }\end{array}$} \\
\hline & & & & \\
\hline 1 & $.302^{\mathrm{a}}$ & .091 & .073 & 32.90335 \\
\hline
\end{tabular}

a. Predictors: (Constant), QR, DER

b. Dependent Variable: DPR

Source: Output calculation of SPSS version 25

From the table above it can be seen that the coefficient of determination or Adjusted $\mathrm{R}$ Square is 0.73 or $73 \%$ means that Debt to Equity Ratio and Quick Ratio have an effect on the Dividend Payout Ratio of $73 \%$ while the rest $(100 \%-73 \%=27 \%)$ is influenced by other variables not used in this study.

\subsection{Overall Significance Test}

The overall significant test (F statistic test) is used to test whether the independent variable Return On Assets, Debt to Equity Ratio and Quick Ratio simultaneously or jointly influence the dependent variable namely Dividend Payout Ratio.

Table 8. ANOVA ${ }^{\mathrm{a}}$

\begin{tabular}{|l|l|c|r|c|c|c|}
\hline \multicolumn{2}{|l|}{ Model } & $\begin{array}{c}\text { Sum of } \\
\text { Squares }\end{array}$ & df & $\begin{array}{c}\text { Mean } \\
\text { Square }\end{array}$ & F & Sig. \\
\hline \multirow{3}{*}{1} & Regression & 11080.628 & 2 & 5540.314 & 5.117 & $.008^{\mathrm{b}}$ \\
\cline { 2 - 8 } & Residual & 110428.304 & 102 & 1082.630 & & \\
\cline { 2 - 8 } & Total & 121508.931 & 104 & & & \\
\hline
\end{tabular}

a. Dependent Variable: DPR

b. Predictors: (Constant), QR, DER

Based on the table above, it is known that the value of the $\mathrm{F}$ test is 5.117 with a significant value of 0.008 . Significant value obtained $<0.05$ which means that the regression model can be used to predict the dependent variable, Dividend Payout Ratio. Significance value of 0.008 is smaller than the value of a significant level of alpha that has been determined 5\% (0.050). It can be concluded that Debt to Equity Ratio and Quick Ratio in this study jointly influence the Dividend Payout Ratio significantly.

\subsection{Individual Parameter Significance Test}


Significant test of individual parameters or $t$ test statistics is used to determine whether each independent variable has an effect on the dependent variable. The statistical test used in this partial test is the $t$ test. The basis for acceptance or rejection of hypotheses can be seen from significant values. If the significant level of t count is smaller than the significant level of alpha $5 \%(0.050)$, it can be concluded that the independent variable has a significant effect on the dependent variable.

Table 9. : Output perhitungan SPSS versi 2

Coefficients $^{\mathrm{a}}$

\begin{tabular}{|c|c|c|c|c|c|c|}
\hline \multirow{2}{*}{\multicolumn{2}{|c|}{ Mod }} & \multicolumn{2}{|c|}{$\begin{array}{l}\text { Unstandardized } \\
\text { Coefficients }\end{array}$} & \multirow{2}{*}{ 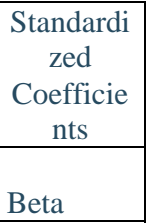 } & \multirow[b]{2}{*}{$\mathrm{t}$} & \multirow[b]{2}{*}{ Sig. } \\
\hline & & B & $\begin{array}{l}\text { Std. } \\
\text { Error }\end{array}$ & & & \\
\hline \multirow[t]{3}{*}{1} & $\begin{array}{l}\text { (Consta } \\
\text { nt) }\end{array}$ & $\begin{array}{r}13.48 \\
9 \\
\end{array}$ & 6.820 & & $\begin{array}{r}1.97 \\
8 \\
\end{array}$ & .051 \\
\hline & DER & .067 & .044 & .154 & $\begin{array}{r}1.53 \\
3 \\
\end{array}$ & .128 \\
\hline & QR & .073 & .023 & .318 & $\begin{array}{r}3.16 \\
3 \\
\end{array}$ & .002 \\
\hline
\end{tabular}

a. Dependent Variable: DPR

To find out how far the influence of independent variables on the dependent variable can be done by comparing the value of $t$ count with t table. If the significant value of $t$ count is higher than the value of table, then there is a significant effect.

Based on the results of the t-test in the table above, the results of the analysis are as follows:

a. The variable Return On Assets (ROA) does not test the significance of individual parameters and has been eliminated because heteroscedasticity occurs.

b. The value of $t$ calculated Debt to Equity Ratio (DER) is 1.533 with a significance level of 0.128 . These results indicate that the DER significance value is greater than the significance level of $0.128>0.050$, so the conclusion $\mathrm{H} 1$ is rejected or there is no influence between DER variables on dividend policy (DPR).

The value of $t$ Quick Quick ratio (QR) is 3.163 with a significance level of 0.002 . These results indicate that the QR significance value is greater than the significance level of $0.002>$ 0.050 , so the conclusion $\mathrm{H} 1$ is accepted or there is an influence between $\mathrm{QR}$ variables on dividend policy (DPR).

\subsection{Test of Multiple Linear Regression Analysis}

In this study, multiple linear regression analysis was used to determine the effect or relationship between ROA (X1), DER (X2), QR (X3) on dividend policy or DPR (Y). The results of multiple linear regression analysis can be seen in the following table:

Table 10. Source: Output calculation of SPSS version 25 
Coefficients $^{\mathrm{a}}$

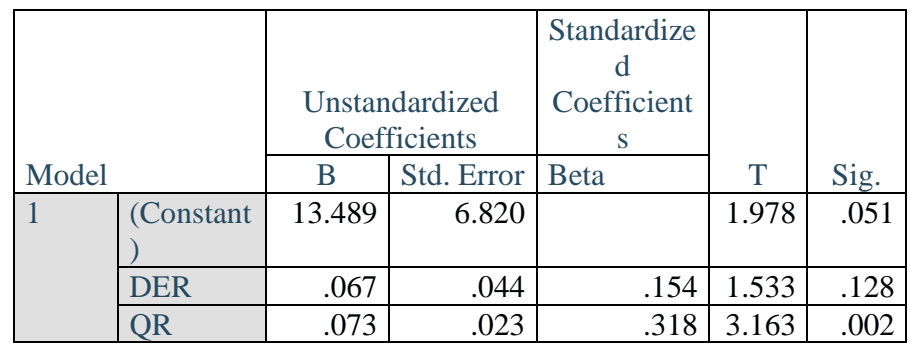

a. Dependent Variable: DPR

Based on the table above, the multiple linear regression equation model is obtained and the analysis results obtained are as follows:

$\mathrm{DPR}=13,489+0.067 \mathrm{DER}+0.073 \mathrm{QR}$

The coefficients in the above equation can be explained as follows:

1. Constant (a) of 13,489 and positive, this shows that if DER and QR are constant, the dividend policy will be 13,489 .

2. Regression Coefficient (B)

a. ROA variable is not tested by multiple linear regression analysis and has been eliminated due to heteroscedasticity.

b. A positive DER value of 0.067 means that if the Debt to Equity Ratio increases, the dividend policy will increase by 0.067 .

c. A positive QR value of 0.073 means that if the Quick Ratio increases, the dividend policy will increase by 0.073 .

Based on the calculation using the $\mathrm{t}$ test, it is known that the Debt to Equity Ratio (DER) variable does not affect dividend policy, while the Quick Ratio (QR) variable influences dividend policy in the consumer goods manufacturing industry listed on the Indonesia Stock Exchange (IDX) in the period 2015-2017. The variable Return On Assets (ROA) in this study was eliminated because heteroscedasticity occurred.

Table 11. Summary of Research Results Hypothesis

\begin{tabular}{|l|l|l|}
\hline Kode & Hipotesis & Conclusion \\
\hline $\mathrm{H}_{1}$ & $\begin{array}{l}\text { Return On Asset has a positive effect on } \\
\text { Dividend Policy }\end{array}$ & Eliminated \\
\hline $\mathrm{H}_{2}$ & $\begin{array}{l}\text { Debt to Equity Ratio has a negative effect on } \\
\text { Dividend Policy }\end{array}$ & Not acceptable \\
\hline $\mathrm{H}_{3}$ & $\begin{array}{l}\text { Quick Ratio has a positive effect on Dividend } \\
\text { Policy }\end{array}$ & Be accepted \\
\hline
\end{tabular}

\section{Effect of Return On Assets on Dividend Policy.}

Variables of Return On Assets (ROA) are not tested for hypotheses and have been eliminated due to heteroscedasticity. 


\section{Effect of Debt to Equity Ratio on Dividend Policy.}

The results of testing on $\mathrm{H} 2$ indicate that the Debt to Equity Ratio does not affect dividend policy. This is in accordance with the results of research conducted by Ery Teguh Prasetyo (2017) and Ni Ketut Ari Astiti et al (2017), namely the debt to equity ratio does not affect the dividend payout ratio (12),(13). The results of this study explain that the high and low DER does not affect management in setting dividend policy.

3. Effect of Quick Ratio on Dividend Policy.

The results of testing on $\mathrm{H} 3$ indicate that the Quick Ratio has an effect on dividend policy. This is in accordance with the results of research conducted by Amyas et al (2014) and Kristina Simbolon and Djoko Sampurno (2017) in their research to conclude that the quick ratio has a positive effect on the dividend payout ratio (23)(24). The results of this study explain that the high and low QR affects management in setting dividend policy.

\section{Result And Discussion}

This study examines whether return on assets, debt to equity ratio, quick ratio has a significant influence on dividend policy which is represented by a dividend payout ratio in consumer goods manufacturing sector companies listed on the Indonesia Stock Exchange (IDX) in the 2015 to 2017 research period .

The results of the study indicate that:

1. Return On Assets cannot be tested for hypotheses and have been eliminated due to heteroscedasticity.

2. Debt to Equity Ratio does not affect dividend policy. This means that the level of corporate debt does not affect the company's dividend policy, so H2 cannot be accepted.

Quick Ratio affects the dividend policy. This means that the level of company liquidity affects the company's dividend policy, so H3 is accepted.

\section{Suggestion}

The suggestions for the next researcher are suggested to increase the number of samples and adjust to the current conditions according to the research year. 


\section{References}

1. M Hanafi M dan AH. Analisis Laporan Keuangan e5. Yogyakarta : UPP AMP YKPN. 2016;

2. Fahmi I. Manajemen Keuangan Perusahaan Dan Pasar Modal. Jakarta : Mitra Wacana Media. 2014;

3. Kieso, Donald E., Jerry J. Weygandt \& TDW. Akuntansi Keuangan Menengah Volume 2. Jakarta : Salemba Empat. 2018;

4. Firdaus I dan SR. Pengaruh Profitabilitas, Likuiditas dan Struktur Modal Terhadap Kebijakan Deviden. Jurnal Ilmiah Manajemen dan Bisnis. 2017;

5. Sumampow S, Murni S. Pengaruh Return Saham, Price Book Value Dan Return on Asset Terhadap Dividend Payout Ratio Pada Perusahaan Yang Terdaftar Di Bei (Studi Pada Perusahaan Telekomunikasi). J Ris Ekon Manajemen, Bisnis dan Akunt. 2016;4(2):1-7.

6. Bushra A dan NM. The Determinants of Corporate Dividend Policy in Pakistan. The Lahore Journal of Economics. 2015;

7. Văidean VL dan CZM. The Determinants Of Dividend Policy. Review of Economic Studies and Research Virgil Madgearu. 2015;

8. Novianti ZEW. Pengaruh Profitabilitas, Growth, Kebijakan Hutang Dan Kepemilikan Institusional Terhadap Kebijakan Dividen. Jurnal Ilmu dan Riset Akuntansi. 2017;

9. Tulung, Joy PK dan SM. Pengaruh Kinerja Keuangan Terhadap Kebijakan Dividen Pada Bank Bumn Yang Go Public Di Bursa Efek Indonesia Tahun 2011-2015. EMBA. 2017;

10. Pornumpai K 2013. Factors Influencing Dividend Payout in Thailand: A Tobit Regression Analysis. International Journal of Accounting and Financial Reporting. 2013;

11. Windyasari HR. Windyasari, Herlina Raiza. Pengaruh Return Asset, Debt To Equity Ratio, Dan Collat Asset Terhadap Kebijak Divid J Ilmu dan Ris Akunt. 2017;

12. Prasetyo ET. 2017. Debt to Equity Ratio dan Return on Asset Pengaruhnya Terhadap Dividen Payout Ratio (Studi Kasus Perusahaan Manufaktur di BEI Periode 20082011). Jurnal Kajian Ilmiah Universitas Bhayangkara Jakarta Raya. 2017;

13. Astiti KA, Yuniarta GA, Sujana E. Pengaruh Debt To Equity Ratio ( Der ), Current Ratio ( Cr ), Net Present Margin ( Npm ), Return on Asset ( Roa ), Terhadap Dividend Payout Ratio ( Dpr ) Studi Pada Perusahaan Basic Industry Dan Properti, Real Estate \& Building Contruction Yang Terdaftar. e-journal S1 Ak Univ Pendidik Ganesha. 2017;7(1).

14. Al-khadhiri A, Alzomaia TS. Determination of Dividend Policy: The Evidence from Saudi Arabia. Int J Bus Soc Sci [Internet]. 2013;4(1):181-92. Available from: www.ijbssnet.com

15. Andriani. Faktor-Faktor Yang Mempengaruhi Kebijakan Dividen Pada Perusahaan Consumer Goods di BEI. Jurnal Ilmu dan Riset Akuntansi. 2017;

16. Tatang Ary Gumanti. Kebijakan Dividen Teori Empiris Dan Implikasi. Kebijak Divid Teor Empiris dan Implikasi. 2013;1:240.

17. R Murhadi W 2015. Analisis Laporan Keuangan : proyeksi dan valuasi saham. Jakarta : Salemba Empat. 2015;

18. hery. Analisis Laporan Keuangan Pendekatan Rasio Keuangan. Yogyakarta : PT. Buku Seru. 2015; 
19. Kasmir. Analisis laporan keuangan. Jakarta : PT Raja Grfaindo Persada. 2017;

20. Jumingan. Analisis Laporan Keuangan. Jakarta : Bumi Aksara. 2014;

21. Home, James C. Van dan John M. Wachowicz J. Prinsip-Prinsip Manajemen Keuangan. Jakarta : Salemba Empat. 2016;

22. Ghozali I 2016. Aplikasi Analisis Multivariete Dengan Program IBM SPSS 23. Semarang : Badan Penerbit Universitas Diponegoro. 2016;

23. Amyas, M. A., \& Basri H (2014). Pengaruh Quick Ratio, Earning Per Share, Dan Return On Investment Terhadap Dividen Kas Pada Perusahaan Manufaktur Sektor Food And Beverages Yang Terdaftar Di Bursa Efek Indonesia. 2014;3(1):1-9.

24. Simbolon K dan DS. Analisis Pengaruh Firm Size, DER, Asset Growth, ROE, EPS, Quick Ratio dan Past Dividend terhadap Dividend Payout Ratio (Studi pada Perusahaan Manufaktur yang Terdaftar di BEI Tahun 2011-2015). Diponegoro Journal of Management. 2017; 